\title{
Early p53 mutations in nondysplastic Barrett's tissue detected by the restriction site mutation (RSM) methodology
}

\author{
GJS Jenkins**, SH Doak², AP Griffiths ${ }^{3}$, N Tofazzal ${ }^{3}$, V Shah ${ }^{4}$, JN Baxter ${ }^{5}$ and JM Parry ${ }^{2}$ \\ 'Swansea Clinical School, University of Wales Swansea, Singleton Park, Swansea SA28PP, UK; ${ }^{2}$ School of Biological Sciences, University of Wales Swansea, \\ Singleton Park, Swansea SA28PP, UK; ${ }^{3}$ Department of Histopathology, Morriston Hospital, Morriston, Swansea SA6 6NL, UK; ${ }^{4}$ Department of \\ Histopathology, Singleton Hospital, Swansea SA2 8QA, UK; ${ }^{5}$ Department of Surgery, Morriston Hospital, Morriston, Swansea SA6 6NL, UK
}

Barrett's oesophagus is a premalignant condition whose incidence is rising dramatically. Molecular markers are urgently needed to identify Barrett's patients at the highest risk of cancer progression. To this end, we have used a rapid molecular technique, restriction site mutation (RSM), to detect low-frequency mutations in the p53 tumour suppressor gene in premalignant Barrett's tissues of cancer-free patients. In total, 38 endoscopically diagnosed Barrett's patients with a range of histological stages of Barrett's progression, plus four control patients without Barrett's oesophagus, were analysed for early p53 mutations. Tissue samples taken from these patients (93 samples in total) were analysed for the presence of low-frequency p53 mutations at hotspot codons: 175, 21 3, 248, 249, 282. In total, 13 of the 38 Barrett's patients were shown to possess a p53 mutation in at least one sample (no mutations in the four control patients). Although no statistically significant associations were found, p53 mutations reflected histological progression in Barrett's patients with p53 mutations found in 30\% of metaplasia patients $(P=0.4)$ and low-grade dysplasia patients $(P=0.33)$ and $45 \%$ of high-grade dysplasia patients $(P=0.15)$. Detected p53 mutations were mainly GC to AT transitions at CpG sites. British Journal of Cancer (2003) 88, I27I - I276. doi:I0.1038/sj.bjc.660089I www.bjcancer.com (c) 2003 Cancer Research UK

Keywords: mutation; p53 gene; biomarker; Barrett's oesophagus

Barrett's metaplasia is a precursor of adenocarcinoma of the oesophagus, the incidence of which is rising dramatically in Western countries (Watson, 2000). Metaplastic Barrett's epithelium may progress through low-grade dysplasia (LGD) and highgrade dysplasia (HGD) to cancer. Patients with a metaplastic Barrett's segment have a 30-125-fold greater risk of adenocarcinoma than non-Barrett's patients (Cameron et al, 1985). The driving force behind cancer development in Barrett's tissues is thought to be oesophageal inflammation induced by chronic reflux of stomach acid and duodenal fluid (Chen and Yang, 2001). Inflamed tissues are known to be cancer prone (Ambs et al, 1999), partly because of their increased cell proliferation rates (Sjoqvist et al, 1999). The reactive oxygen species (ROS) produced during such inflammation (e.g. superoxide, hydrogen peroxide, nitric oxide) are complete carcinogens in their own right (Cerutti and Trump, 1991; Dreher and Junod, 1996). However, coincident exposure of inflamed tissues to mutagens (possibly bile acids in the case of Barrett's patients) can exacerbate carcinogenesis.

Progression of Barrett's metaplasia to adenocarcinoma is accompanied by a range of genetic alterations (Fitzgerald and Triadafilopoulos, 1998; Jankowski et al, 1999; Jenkins et al, 2002), including loss of p53 tumour suppressor function. The most common mechanism of p53 loss is through the accumulation of mutations at one of eight hotspot codons (Hainaut and Hollstein, 2000). p53 loss is significant in cancer development because of the role that p53 plays in maintaining genomic stability. It is well

*Correspondence: Dr GJS Jenkins; E-mail: g.j.jenkins@swansea.ac.uk Received 16 September 2002; revised 7 January 2003; accepted 4 February 2003 known that p53 loss leads to increased spontaneous mutation rates (Havre et al, 1995), chromosome instability (Bouffler et al, 1995) and aneuploidy (Fukasawa et al, 1996). These latter two events are characteristic of Barrett's progression (Jenkins et al, 2002). Indeed, it has been shown that p53 mutation precedes (and perhaps leads to) aneuploidy in Barrett's tissues (Neshat et al, 1994; Prevo et al, 1999).

The role of p53 mutation in Barrett's tumour progression has been studied previously, with p53 mutations being detected in Barrett's tumours and in adjacent dysplastic tissue. However, p53 mutation has been poorly studied in premalignant Barrett's tissues, especially in cancer-free patients (Prevo et al, 1999). This lack of p53 mutation data has led to controversy with respect to the timing of p53 mutation in Barrett's progression (Fitzgerald and Triadafilopoulos, 1998). Table 1 contains a list of published p53 mutation data for Barrett's tissues. Most of these data come from tumour samples, with some data available for adjacent premalignant Barrett's tissue (mostly dysplasia). The data in Table 1 are solely derived from molecular studies on p53 gene mutations in Barrett's tissue and do not include the inference of p53 mutations by immunohistochemistry (IHC). Using IHC as a surrogate for p53 mutation has been widely described as unsatisfactory (Hamelin et al, 1994; Schneider et al, 1996; Gleeson et al, 1998). From Table 1, it is evident that while some authors claim that p53 mutations are detectable in metaplastic tissue (Casson et al, 1991) or low-grade dysplastic tissue (Gleeson et al, 1998; Bian et al, 2001), most authors only detect mutations in tissues containing high-grade dysplasia or cancer (Hamelin et al, 1994; Audrezet et al, 1996). This discrepancy is probably because of the methodological shortcomings of these studies (Minamoto and Ronai, 2001). It is well known that there is an inverse correlation between the 
abundance of a genetic alteration (e.g. p53 mutation) and the ease with which it is detected (Minamoto and Ronai, 2001). In order to detect early p53 mutations in premalignant tissue of cancer-free patients, methodologies must enrich for mutated sequences at the expense of the more abundant nonmutated sequences (Minamoto and Ronai, 2001).

In this paper, we present a relatively simple molecular technique called restriction site mutation (RSM) (Jenkins et al, 1999, $2001 \mathrm{a}, \mathrm{b})$ and assess its ability to detect early p53 mutations in premalignant Barrett's tissues from patients without clinically detectable adenocarcinoma. This approach has previously been employed in detecting p53 mutations in ulcerative colitis patients (Ambs et al, 1999) and gastritis patients (our laboratory, unpublished results). Restiction site mutation couples the sequence specificity of restriction enzymes to the amplification power of PCR in order to 'fish out' low-frequency mutated p53 sequences from among excess nonmutated sequences. The RSM technique exploits the fact that five of the eight main p53 mutation hotspots detected in cancers, that is, codons $175,213,248,249,282$, contain restriction enzyme sites, thus allowing RSM to detect lowfrequency mutations at these codons. In previous studies, we have shown that using spiked DNA samples, mutated hotspots are detectable even when in the presence of a 10000-fold excess of nonmutated sequences (Jenkins et al, 2001a,b).

The aim of this prospective study was to (i) assess whether RSM could detect early p53 mutations in premalignant Barrett's tissue, (ii) correlate the presence of any early p53 mutations with histological grade and (iii) assess the value of early p53 mutation as a biomarker for cancer risk in Barrett's patients.

\section{MATERIALS AND METHODS}

\section{Collection of biopsies from Barrett's patients}

Biopsies were obtained from consenting Barrett's patients during routine endoscopy clinics (ethical approval obtained). Biopsies for DNA analysis were obtained from Barrett's mucosa immediately adjacent to the biopsy sites for mucosa sent for histopathological analysis. These biopsies were obtained using large forceps and the whole biopsy $(\sim 10 \mathrm{mg})$ was required for DNA extraction in order to provide sufficient DNA $(\sim 30 \mu \mathrm{g})$ for mutation analysis. Histopathological staging of the Barrett's patients was determined by the consensus view of a panel of three pathologists (APG, NT, VS). Barrett's patients were graded as dysplastic even if this was evident in only one of the biopsy specimens examined, as previously described (Prevo et al, 1999). A total of 38 patients with a range of histopathological stages of Barrett's oesophagus were recruited over a 12-month period (follow up: 9-20 months). Biopsies in four patients contained only squamous epithelium, 13 had Barrett's metaplasia without dysplasia, 14 had LGD and seven had HGD. In addition, paraffin-embedded archival tissue sections from surgically resected tissues were used to increase the numbers of HGD patients from seven to 11. From these 42 patients, 93 tissue samples were collected (average two biopsies per patient). The seven biopsies obtained from the four patients with squamous epithelium were considered as an internal control group in this study. Biopsies were immediately stored on ice until DNA extraction could be performed.

\section{DNA extraction}

Biopsies were minced on a clean microscope slide using a clean scalpel blade. The minced tissues were then subjected to DNA extraction using a high-salt approach (Stratagene, Cambridge, $\mathrm{UK})$. In the case of the paraffin-embedded tissue sections, the tissue was first scraped off five $5 \mu \mathrm{m}$ slides and incubated with $500 \mu \mathrm{l}$ of xylene to dissolve the paraffin. The tissue was 
Table 2 Details of the restriction enzymes employed in this study to detect p53 mutations at key tumour hotspot codons; also included are the PCR primer sequences for each hotspot codon and the amplification conditions

\begin{tabular}{|c|c|c|c|c|c|c|c|}
\hline p53 exon & $\begin{array}{l}\text { Restriction } \\
\text { enzymes }\end{array}$ & $\begin{array}{c}\text { Digestion } \\
\text { temperature }\left({ }^{\circ}\right)\end{array}$ & $\begin{array}{l}\text { Forward } \\
\text { primer }\end{array}$ & $\begin{array}{l}\text { Reverse } \\
\text { primer }\end{array}$ & $\begin{array}{c}\text { PCR } \\
\text { product } \\
\text { size (bp) }\end{array}$ & $\begin{array}{c}\text { Anneal } \\
\text { temperature } \\
\text { ( } \mathrm{C})\end{array}$ & $\begin{array}{l}\text { Cycle } \\
\text { number }\end{array}$ \\
\hline Condon 175 & Hha I GCGC & 37 & $\begin{array}{l}\text { ccgcgccatggc } \\
\text { catct }\end{array}$ & $\begin{array}{l}\text { gcgctcatggtgg } \\
\text { ggg }\end{array}$ & 75 & 60 & 31 \\
\hline $\begin{array}{l}\text { Exon } 6 \\
\text { Condon } 213\end{array}$ & Taq I TCGA & 65 & $\begin{array}{l}\text { gtccccaggcct } \\
\text { ctgattcctc }\end{array}$ & $\begin{array}{l}\text { taacccctcctccc } \\
\text { agagaccccag }\end{array}$ & 188 & 65 & 34 \\
\hline Condon 282 & Msp I CCGG & 37 & $\begin{array}{l}\text { cctcttgcttctcttt } \\
\text { tcctatcc }\end{array}$ & $\begin{array}{l}\text { cttggtctcctccac } \\
\text { cgcttcttg }\end{array}$ & 262 & 60 & 31 \\
\hline
\end{tabular}

subsequently pelleted by centrifugation and washed with $70 \%$ ethanol before proceeding with the DNA extraction (as above). After DNA extraction, the quantity and purity of the DNA was assessed by spectrophotometry at $260 / 280 \mathrm{~nm}$ and by $1 \%$ agarose electrophoresis. The DNA concentration was adjusted to $100 \mathrm{ng} \mu \mathrm{l}^{-1}$ and the DNA stored at $-20^{\circ} \mathrm{C}$.

\section{Restriction site mutation analysis}

The DNA extracted from oesophageal tissue samples was analysed for mutations occurring in five restriction enzyme sites of the human p53 gene. These restriction sites covered the hotspot codons 175, 213, 248, 249 and 282. A total of 465 RSM analyses were performed with the Barrett's samples (93 tissue samples analysed at each of five restriction enzyme sites). Table 2 contains details of the restriction enzymes used and the PCR conditions employed to amplify the mutant sequences. A previous study by ourselves has shown that using spiked tumour DNA bearing a p53 mutation, the RSM method can detect such mutations even when present among a 10000-fold excess of nonmutated DNA (Jenkins et al, 2001a,b).

Initial digestion DNA ( $1.5 \mu \mathrm{g}$ containing $4 \times 10^{5}$ copies of the p53 gene) was subject to restriction digestion with $10-20 \mathrm{U}$ of the particular enzyme under test. In the case of the paraffin-embedded tissue sections, the low yield of DNA meant that only $500 \mathrm{ng}$ of DNA was included in the RSM analysis. The initial digestion was performed in a volume of $20 \mu \mathrm{l}$ of magnesium-free Taq Polymerase buffer (Promega Corporation, Southampton, UK) supplemented with $1.5 \mathrm{mM} \mathrm{MgCl}_{2}$. The digestion was performed at the optimum temperature overnight $(16 \mathrm{~h})$. The following morning, a further $10 \mathrm{U}$ of restriction enzyme was added for $1 \mathrm{~h}$, to ensure maximum digestion of the nonmutated DNA.

Polymerase chain reaction amplification Following digestion, the undigested (mutated) sequences were amplified by PCR using primers (Table 2) flanking the restriction site under examination (Cruachem, Glasgow, Scotland). The PCR amplification was performed in $1 \times$ magnesium-free Taq polymerase buffer (Promega Corp.), along with $1.5 \mathrm{mM} \mathrm{MgCl}_{2}, 100 \mu \mathrm{M}$ dNTPs (Promega Corp.), 10 pmol of each primer (Cruachem), $20 \mu \mathrm{l}$ of digested DNA and $2.5 \mathrm{U}$ of Taq polymerase (Promega Corp.), in a final volume of $50 \mu \mathrm{l}$. Positive (uncut DNA) and negative (no DNA) controls for the PCR step were also included.

Final digestion After amplification, the PCR product $(16 \mu \mathrm{l})$ was further digested overnight in a final volume of $20 \mu \mathrm{l}$, with $10 \mathrm{U}$ of

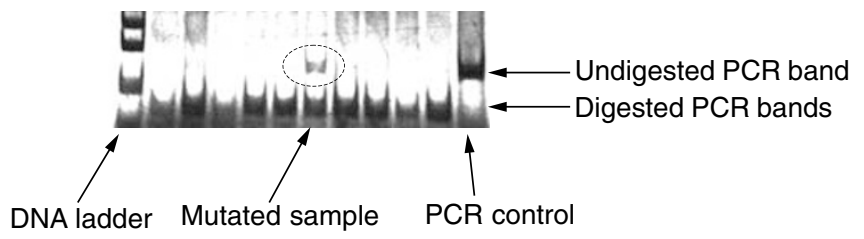

Figure I Example of an RSM experiment involving the Msp I restriction enzyme of codon 248 and DNA extracted from nine Barrett's tissues. The right-hand lane contains a positive control for the PCR step and shows the expected PCR band size. The left-hand lane contains a DNA ladder showing the 100,200 and 300 bp bands. The central lanes contain DNA from Barrett's biopsies subject to RSM analysis. The highlighted lane contains an undigested band of the correct size and was subject to DNA sequencing where it was confirmed that it contained a GC to AT mutation. The remaining lanes (including the internal digestion control situated next to the PCR-positive control) have digested and hence do not contain mutations in this restriction site (codon 248)

the restriction enzyme under test (this time in enzyme-specific digestion buffer) to remove any wild-type sequences that may have escaped the initial digestion.

Electrophoresis The RSM products were then visualised on $5 \%$ polyacrylamide gels (Biorad, Hemel Hempstead, UK) and poststained with silver. Restriction enzyme-resistant RSM products were detected on the gels as undigested bands of the correct size, by comparison to the PCR-positive control (see Figure 1).

As a control for inefficient enzyme digestion, all RSM experiments included commercially obtained human DNA (Promega Corp.) deemed to be free from mutations. Complete digestion of this control was a prerequisite for accepting mutations in accompanying samples. Fisher's exact test was employed to compare the frequency of p53 mutations between histologies.

\section{Sequencing}

Mutations detected in this study by their resistance to restriction enzyme digestion were all confirmed by DNA sequencing. Enzymeresistant products were reamplified by PCR using $1 \mu \mathrm{l}$ of the final RSM product (amplification for 10-12 cycles using appropriate thermal profiles). The reamplified samples were electrophoresed on $5 \%$ polyacrylamide gels and stained with silver to ensure that discrete bands were produced. These PCR products were then sequenced using a cycle sequencing kit (Beckman Coulter, High Wycombe, UK) and run on an automated DNA sequencer 
Table 3 p53 mutations detected in this study; details of the histology of the patients bearing p53 mutations are included, along with details of the mutation itself (base change, amino-acid change)

\begin{tabular}{|c|c|c|c|c|c|}
\hline $\begin{array}{l}\text { Patient } \\
\text { number }\end{array}$ & $\begin{array}{l}\text { Histological } \\
\text { stage }\end{array}$ & $\begin{array}{l}\text { Mutations } \\
\text { per biopsy }\end{array}$ & $\begin{array}{l}\text { Mutated } \\
\text { p53 condon }\end{array}$ & $\begin{array}{l}\text { p53 } \\
\text { mutation }\end{array}$ & $\begin{array}{l}\text { Amino-acid } \\
\text { change }\end{array}$ \\
\hline 2 & HGD & $1 / 2$ & I at 248 & cgg-cag & Arg-Gln \\
\hline 3 & HGD & $2 / 4$ & 2 at 248 & cgg-cag & Arg-GIn \\
\hline 4 & HGD & $7 / 8$ & 7 at 248 & cgg-cag & Arg-Gln \\
\hline 6 & $\mathrm{BM}$ & $2 / 5$ & 2 at 248 & cgg-cag & Arg-Gln \\
\hline 8 & HGD & $2 / 5$ & 2 at 248 & cgg-cag & Arg-Gln \\
\hline 12 & BM & $1 / 2$ & | at 175 & $\mathrm{cgc}-\mathrm{cac}$ & Arg-His \\
\hline \multirow[t]{2}{*}{13} & LGD & $2 / 6$ & I at 175 & $\operatorname{cgc} \mathrm{c} \operatorname{tgc}$ & Arg-Gln \\
\hline & & & I at 248 & cgg-cag & Arg-Cys \\
\hline 18 & BM & $1 / \mid$ & I at 248 & cgg-cag & Arg-Gln \\
\hline 26 & LGD & $2 / 2$ & 2 at 282 & cgg-cgt & No change \\
\hline 31 & LGD & $1 / 2$ & I at 248 & cgg-cag & Arg-Gln \\
\hline 33 & $\mathrm{BM}$ & $1 / 2$ & I at 248 & cgg-tgg & Arg-Trp \\
\hline \multirow[t]{2}{*}{38} & LGD & $3 / 2$ & 2 at 248 & cgg-cag & Arg-Gln \\
\hline & & & I at 175 & $\mathrm{cgc}-\mathrm{cac}$ & Arg-His \\
\hline 42 & HGD & $|/|$ & I at 248 & cgg-tgg & Arg-Trp \\
\hline
\end{tabular}

(CEQ2000 Beckman Coulter). Both strands were sequenced and only mutations apparent on both strands were accepted. In the case of the exon 5 mutated sequences, the PCR product (75 bp) was too small to be sequenced directly and was firstly cloned using the TA cloning method (Invitrogen NV Leek, The Netherlands).

\section{RESULTS}

\section{Detection of p53 mutations in Barrett's tissues}

No p53 mutations were detectable in any of the biopsies taken from the four patients with squamous epithelium, nor were any undigested products obtained with the internal digestion control. This suggests that mutation artefacts were not introduced during the methodology and that all mutations subsequently detected were genuinely present in the Barrett's tissues. Table 3 contains the details of the p53 mutations detected in Barrett's tissues. In total, 13 of the 38 patients with Barrett's oesophagus (36\%) were shown to contain p53 mutations in at least one of their biopsies. Two patients (patients 13 and 38) possessed different p53 mutations in different biopsies, and seven out of 13 patients containing mutations were shown to contain a p53 mutation in more than one biopsy (with patient 4 having seven identical p53 mutations recovered from the eight biopsies available). The fact that seven out of eight different biopsies of patient 4 produced an identical p53 mutation may be considered a validation of the reproducibility of this approach in detecting p53 mutations in Barrett's tissues.

\section{Correlation of p53 mutation with histology}

Of the 13 patients who were histologically classed as having metaplasia, four patients possessed a p53 mutation in at least one biopsy. In the case of LGD, four out of 14 patients possessed a p53 mutation. Of the 11 patients with HGD, a further five contained p53 mutations in a least one biopsy (see Figure 2). There was no statistically significant difference in the number of p53 mutations in squamous tissue $v s$ metaplastic tissue $(P=0.4)$, or low-grade dysplastic tissue $(P=0.33)$ or high-grade dysplastic tissue $(P=0.15)$. The reported incidence of $\mathrm{p} 53$ gene mutation in adenocarcinomas is in the range $50-88 \%$ (Table 1), which corresponds well with the trend shown in Figure 2. However, it should be pointed out that we used a method here with a

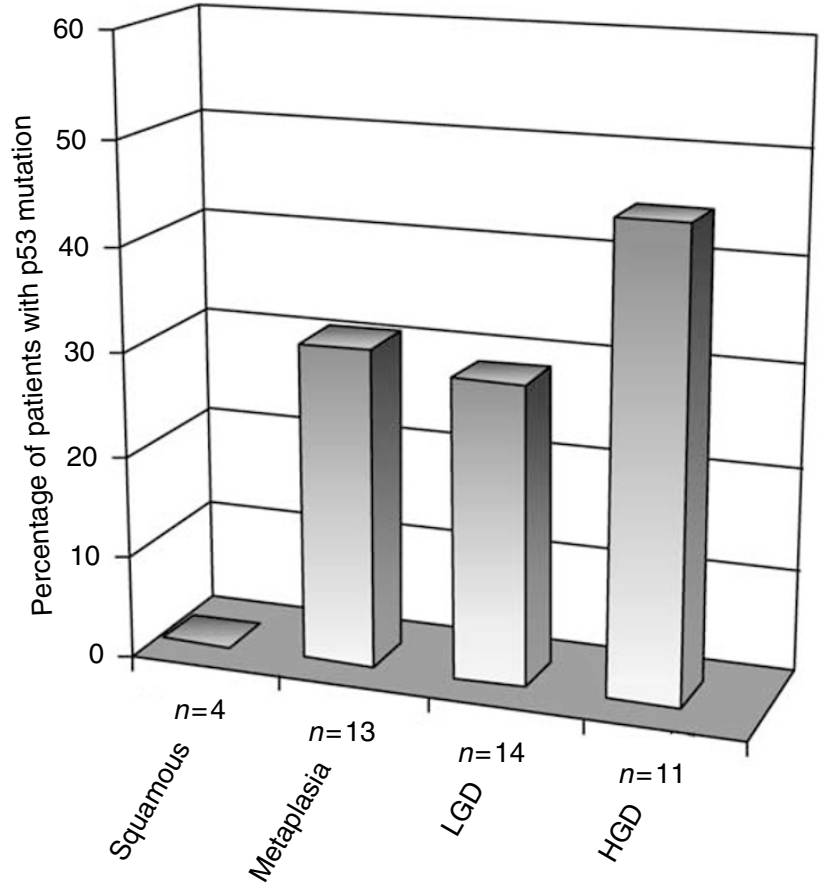

Figure 2 Role of p53 mutation in Barrett's progression. The proportion of patients with $\mathrm{p} 53$ mutations are correlated with histological grade. This figure shows the accumulation of $p 53$ mutation with histological grade. From Table I it can be seen that $50-88 \%$ of adenocarcinomas have been shown to contain p53 mutations. Hence fitting well with the trend observed in this figure, however, the differing sensitivities of the methods used make true comparison difficult.

reasonably high sensitivity, whereas the previously published data were obtained with low-sensitivity methods, and hence comparisons may be difficult.

Seven of the 13 patients with p53 mutations were shown to contain multiple mutated tissue samples. As an indication of the clonal expansion of p53 mutated cells, six of these were dysplastic patients (three LGD, three HGD), suggesting that this clonal expansion step was linked to the histological progression of Barrett's tissues $(P=0.13)$. 


\section{p53 mutation types detected in Barrett's tissues}

A total of 26 mutational events were detectable in the 465 RSM experiments performed. These mutations were mostly recovered from codon 248 ( $M s p$ I restriction site), with 21 of the mutations $(80 \%)$ being found here, three mutations $(12 \%)$ were recovered from codon 175 (Hha I restriction site), with the final two mutations (8\%) at codon 282 (Msp I restriction site). The fact that the majority of p53 mutations were located at codon 248 suggests that this codon is particularly targeted in Barrett's progression. This is supported by the fact that codon 248 is the most common mutation hotspot in all human tumours (p53 mutation database: www.IARC.fr/p53/) and that Barrett's tumour p53 mutations, in particular, are often located at codon 248 (Table 1). No mutations were recovered from codons 213 ( $T a q$ I restriction site) or 249 (Hae III restriction site), despite reports of frequent polymorphisms in Barrett's patients at codon 213 (Hamelin et al, 1994; Campomenosi et al, 1996). Of the 26 mutations recovered, nearly all $(92 \%)$ were GC to AT transitions at $\mathrm{CpG}$ sites, supporting previous data with regard to p53 mutations in Barrett's tumours (Gleeson et al, 1995, 1998).

\section{DISCUSSION}

Importantly, this study shows that a subset of tissues from nondysplastic Barrett's patients contain p53 mutations that may predispose those patients to tumour development. Previous reports have established that p53 mutation data can be used as a predictive marker for cancer development in Barrett's patients (Schneider et al, 1996), and that the presence of p53 mutations can predict poor 5-year survival rates of Barrett's tumour patients postoperatively (Schneider et al, 2000). p53 mutation has also been shown to be useful as a predictive marker for the occurrence of metastases in Barrett's tumour patients (Casson et al, 1991; Bian et al, 2001). Finally, p53 mutation data have also been used to predict the poor response of Barrett's tumour patients to photodynamic therapy (Krishnadath et al, 2000). p53 mutation therefore shows promise as a biomarker in Barrett's patients (Gleeson et al, 1998; Reid, 2001), but its use as an early biomarker for risk of cancer development relies on its detection as early as possible in premalignant Barrett's tissues.

We have shown here that the application of a molecular technique, that is, RSM, has allowed the detection of low-frequency p53 mutations in premalignant Barrett's tissues. As has been pointed out previously, it is not feasible to use direct DNA sequencing as a clinical tool to detect p53 mutation in Barrett's patients (Reid, 2001). However, the RSM method appears to be well suited in scanning the hotspot codons of p53 for early mutations, which would be undetectable by less-sensitive contemporary techniques. We show that the appearance of p53 mutated cells can occur at the metaplasia stage, with the clonal expansion of these mutated cells occurring at the dysplastic stage.

It is interesting to note that two of the patients were shown to have different p53 mutations in different biopsies, thus indicating that divergent clonal evolution may be occurring in their Barrett's segments. It has previously been suggested that early neoplasia may well have a multifocal nature leading to oligoclonal development (Jankowski et al, 1999). These lines of evidence point to the Barrett's epithelium being the subject of high levels of genetic evolution as a result of continuous exposure to potent mutagenic agents, for example, ROS. Most of the p53 mutations detected were present at $\mathrm{CpG}$ sites. $\mathrm{CpG}$ sites are known to be susceptible to spontaneous deamination of methylated cytosine, leading to the conversion of $\mathrm{C}$ to $\mathrm{T}$ (Pfeiffer, 2000). This process is thought to be enhanced by exposure to ROS (Ambs et al, 1999), possibly implicating inflammation-induced ROS in the development of tumours in Barrett's patients.

There are indeed notable similarities in the mutation profile (types and positions) detected here in Barrett's patients and those p53 mutations previously shown by ourselves to be induced by the model ROS hydrogen peroxide in vitro (Jenkins et al, 2001a,b). This adds weight to the argument that ROS produced during inflammation may play a role in cancer development in Barrett's tissues and may be responsible for the p53 mutations detected here.

The potential value of $\mathrm{p} 53$ as a biomarker depends upon whether it can be shown that possession of a p53 mutation either affects the risk of cancer progression in Barrett's patients, or affects the rate at which this sequence unfolds. Only long-term follow-up of these patients will answer this question. The fact that p53 mutation abundance appears to increase during histological progression suggests that this abnormality plays an important driving role in carcinogenesis in Barrett's tissues.

\section{ACKNOWLEDGEMENTS}

This work was funded by the Biotechnology and Biological Sciences Research Council, The Tenovus Cancer Charity and Swansea NHS Trust.

\section{REFERENCES}

Ambs S, Bennett WP, Merriam WG, Ogunfusika MO, Oser SM, Harrington AM, Shields PG, Felley-Bosco E, PerwezHussain S, Harris CC (1999) Relationship between p53 mutations and inducible nitric oxide synthase expression in human colorectal cancer. J Natl Cancer Inst 91: 86-89

Audrezet MP, Robaszkiewicz M, Mercier B, Nousbaum JB, Hardy E, Bail JP, Volant A, Lozach P, Gouerou H, Ferec C (1996) Molecular analysis of the TP53 gene in Barrett's adenocarcinoma. Hum Mutat 7: 109-113

Bian YS, Osterheld MC, Bosman FT, Benhattar J, Fontolliet C (2001) p53 gene mutation and protein accumulation during neoplastic progression in Barrett's oesophagus. Mod Pathol 14: 397-403

Bouffler SD, Kemp C, Balmain A, Cox R (1995) Spontaneous and ionizing radiation induced chromosomal abnormalities in p53 deficient mice. Cancer Res 55: $3883-3889$

Casson AG, Mukhopadhyay T, Cleary KR, Ro JY, Levin B, Roth JA (1991) p53 gene mutations in Barrett's epithelium and esophageal cancer. Cancer Res 51: 4495-4499

Cameron AJ, Ott BJ, Payne, WS (1985) The incidence of adenocarcinoma in columnar lined (Barrett's) oesophagus. $N$ Eng J Med 313: 857-859

Campomenosi P, Conio M, Bogliola M, Urbani S, Assereto P, Aprile A, Monti P, Aste H, Lapertosa G, Inga A, Abbondandola A, Fronza G (1996) p53 is frequently mutated in Barrett's metaplasia of the intestinal type. Cancer Epidemiol Biomarkers Prevention 5: 559-565

Cerutti PA, Trump BA (1991) Inflammation and oxidative stress in carcinogenesis. Cancer Cells 3: $1-7$

Chen XX, Yang CS (2001) Esophageal adenocarcinoma: a review and perspectives on mechanism of carcinogenesis and chemoprevention. Carcinogenesis 22: 1119-1129

Dreher D, Junod AF (1996) Role of oxygen free radicals in cancer development. Eur J Cancer 32A: 30-38

Fitzgerald RC, Triadafilopoulos G (1998) Recent developments in the molecular characterisation of Barrett's esophagus. Dig Dis Sci 16: $63-80$

Fukasawa K, Choi T, Kuriyama R, Rulong S, VandeWoude GF (1996) Abnormal centrosome amplification in the absence of p53. Science 271: $1744-1747$

Gleeson CM, Sloan JM, McGuigan JA, Ritchie AJ, Russell SHE (1995) Base transitions at $\mathrm{CpG}$ dinucleotides in the p53 gene are common in esophogeal adenocarcinoma. Cancer Res 55: 3406-3411

Gleeson CM, Sloan JM, McManus DT, Maxwell P, Arthur K, McGuigan JA, Ritchie AJ, Russell SHE (1998) Comparison of p53 and DNA content 
abnormalities in adenocarcinoma of the oesophagus and gastric cardia. Br J Cancer 77: 277-286

Hamelin R, Flejou J-F, Muzeau F, Potet F, Larent Puig P, Fekete F, Thomas G (1994) TP53 gene mutations and p53 protein immunoreactivity in malignant and premalignant Barrett's esophagus. Gastroenterology 107: $1012-1018$

Hainaut P, Hollstein M (2000) p53 and human cancer the first ten thousand mutations. Adv Cancer Res 77: $81-137$

Havre PA, Yuan J, Hedrick L, Cho KR, Glazer PM (1995) p53 inactivation by HPV16 E6 results in increased mutagenesis in human cells. Cancer Res 55: $4420-4424$

Jankowski JA, Wright NA, Meltzer SJ, Triadafilopoulos G, Geboes K, Casson AG, Kerr D, Young LS (1999) Molecular evolution of the metaplasia - dysplasia - adenocarcinoma sequence in the esophagus. Am J Pathol 154: 965 - 973

Jenkins GJS, Doak SH, Parry JM, Griffiths AP, Baxter JN (2002) Barrett's metaplasia, the genetic pathways involved in its progression to adenocarcinoma. Br J Surg 89: 824-837

Jenkins GJS, Williams GL, Beynon J, Ye Z, Baxter JN, Parry JM (2001a) Restriction enzymes: a molecular tool for analysing the genetic alterations in cancer progression. Br J Surg 89: 8-20

Jenkins GJS, Suzen HS, Sueiro, RA Parry JM (1999) The restriction site mutation (RSM) assay. A review of the methodology development and the current status of the technique. Mutagenesis 14: $439-448$

Jenkins GJS, Morgan C, Parry EM, Baxter JN, Parry JM (2001b) The detection of mutations induced in vitro in the human p53 gene by hydrogen peroxide with the restriction site mutation (RSM) assay. Mutat Res 498: $135-144$
Krishnadath KK, Wang KK, Taniguchi K, Sebo TJ, Buttar NS, Anderson MA, Lutzke LS, Liu W (2000) Persistent genetic abnormalities in Barrett's esophagus after photodynamic therapy. Gastroenterology 119: $624-630$

Minamoto T, Ronai Z (2001) Gene mutation as a target for early detection in cancer diagnosis. Crit Rev Onco/Hematol 40: 195-213

Neshat K, Sanchez CA, Galipeau PC, Blount PL, Levine DS, Joslyn G, Reid BJ (1994) p53 mutations in Barrett's adenocarcinoma and highgrade dysplasia. Gastroenterology 106: 1589-1595

Prevo LJ, Sanchez CA, Galipeau PC, Reid BJ (1999) p53 mutant clones and field effects in Barrett's esophagus. Cancer Res 59: 4784-4787

Pfeiffer GP (2000) p53 mutational spectra and the role of methylated CpG sequences. Mutat Res 450: 155-166

Reid BJ (2001) p53 and neoplastic progression in Barrett's oesophagus. Am J Gastroenterol 96: 1321 - 1323

Schneider PM, Casson AG, Levin B, Garewal HS, Hoelscher AH, Becker K, Dittler HJ, Cleary KR, Troster M, Siewert JR, Roth JA (1996) Mutations of p53 in Barrett's esophagus and Barrett's cancer: a prospective study of 98 cases. J Thorac Cardiovasc Surg 111: 323-333

Schneider PM, Stoeltzing O, Roth JA, Hoelscher AH, Wegerer S, Mizumoto S, Becker K, Dittler HJ, Fink U, Siewert JR (2000) p53 mutational status improves estimation of prognosis in patients with curatively resected adenocarcinoma in Barrett's esophagus. Clin Cancer Res 6: $3153-3158$

Sjoqvist U, Ost A, Lofberg R (1999) Increased expression of proliferative Ki67 nuclear antigen is correlated with dysplastic colorectal epithelium in ulcerative colitis. Int J Colorectal Dis 14: 107-113

Watson A (2000) Barrett's oesophagus: 50 years on. Br J Surg 87: $529-531$ 